\title{
The Influence of Feedback in Different Way of Learning and the Relationship with Students' Vocabulary Acquisition: Issues in Assessment
}

\author{
Irham Miftakhul Jannah \\ Universitas Mayjen Sungkono, email: irham.miftazain@ gmail.com
}

\begin{abstract}
This paper has three components. They are feedback, the way of learning, and vocabulary acquisition. This research was based on the learning situation that teachers and students have to conduct online learning because of the pandemic Covid 19. This paper elaborates the three components mentioned before. In the process of assessment, feedback is the important part. When students learning at school, teachers will give feedback directly. The way of giving feedback in language learning will influence students' vocabulary acquisition. But, in different way of learning, teachers cannot give feedback directly as in the classroom. This situation gives different influence in students' vocabulary acquisition. Then teachers do the alternative assessment in the process of online learning.
\end{abstract}

Keywords: Feedback, Vocabulary Acquisition, Assessment

\section{INTRODUCTION}

Covid-19 has spread broadly in Indonesia. It has given impact on all side of life, included school activities. The effect of the Covid-19 pandemic has given significant encounters, especially in teaching and learning process in schools/madrasah, where a place that should be the essential place in focusing on students' training seems to be changed with the presence of social limitations, (Jannah et al., 2021). So, teachers and students must do teaching and learning process by online. It means teachers give the material and task through social media by using gadget.

There are some ways that the teachers use in doing online class which can be helped by application. By using applications, the teachers can lead the most common way of instructing and learning proses such as sharing learning materials which can be done through internet as if in the normal situations at the school (Admaja, 2020) . Teachers can assign tasks and provide explanations in text format, or they can use video conferencing to meet with students in person if they prefer. When students switch between learning at school and learning at home, they must adjust to the different environments. 
Having this kind of situation, students have to be accompanied by parents as their guide to study. Definitely, it will influence the way of study when students do learning activities at home. As stated in a research, the strong impact on a child development is home environment, it is included attitude, behavior, personality, believes, and manner related to the progress of the child's language acquisition of both first and second language (Khoiriyah et al., 2018). So, the role of parents and home environment give influential effect on students' achievement in learning.

Teaching is action which does interactively; there is communication among teacher and students. The meaning of teaching which emphasized communication and interactive act, online class and classroom activity has its own influence in learning process. It is also supported by the statement that teaching language done by teacher and students is included attractive activity (Seli, 2015).

Conducting a learning process even in online classes should not leave the assessment process. It is because the assessment is an essential component of the teaching and learning process. The importance emerges from the fact that assessment can improve teaching and can affect students' learning negatively or positively. It also emerges from the purposes in helping educators to set up standards, assessing students' progress and motivating their performance, providing diagnostic feedback, etc.

Assessment refers to an effort to obtain information from the learning process and results to find out how well the performance of an individual or group of individuals to determine a complex characteristic when it is compared to certain learning objectives (Brown,1990). Assessment should be analytic, supporting the teachers with checking students' advancement and learning and to recognize the problems that their students' face or have. It should give the important data and feedback to adjust and reorganize the learning process so that the learning objectives can be obtained (Saeed \& Moqbel, 2002).

Organizing the assessment, even though, it should be done in offline class, it should be prepared maximally. Since the teacher is the leader for their students, teachers should create and analyze the questions they have composed, so that they can get the results of the assessment to their own teaching and learning process. Therefore, it provides feedback on the effectiveness of the learning process and gives students an evaluation on their progress. As Brown (1990) maintains, two major functions can be 
pointed out for classroom assessment: One is to show whether or not the learning has been successful, and the other one is to clarify the expectations of the teachers from the students.

There are four essential parts in assessment, they are: measuring the progress in learning process; students' recommendation for their study; evaluating the way of teaching, comparing the students ability from one to others (Yambi \& Dictionary, 2012). Since its purpose is very crucial, it is very important in conducting the teaching and learning process completed by assessment. There are so many ways can be used by teachers to help them assess the abilities of their students, but it must be adjusted with the students' need. It is because the students have different need, different background of knowledge that may affect the way they study. So that, it requires an alternative assessment to improve all or at least can be agreed by all sides.

Alternative assessment refers to conditions to evaluate the students on what they understand and construct rather than on what they are able to remember and imitate. Alternative assessment directly evaluates students ability and shows their ability to use it (Saeed \& Moqbel, 2002). Alternative assessment should be based on course goals, authentic students' implementation, students' involvement in the assessment cycle, and having a bunch of standards that portray the ideal accomplishment. And also stated that the main concept of language testing or assessment is that it should be reliable, valid, and practical (Shohamy, 2017).

One of the results of conducting the assessment in the process of teaching and learning process is getting feedback. Students and teachers' responses with feedback give significant advantages in education. Feedback is very promising and useful way in education (Douglas, 2014). Feedback is the information of some points in education. About the learners' performance relative to learning goals and also information to leads the changes in students and teachers' behavior. There is wide definition about the intention of feedback, it can be designed to achieve the improvement in students learning, then direct student's current performance to a current learning goal.

The term feedback is often used to describe all kinds of comments made after the fact, including advice, praise, and evaluation. Feedback is information given to the learner and/or the teacher about the learner's performance relative to learning goals. 
Some researchers have conducted the research related with giving feedback after completing assessment. First, it has been conducted by Nahadi et al. (2015). This research applies formative assessment with feedbacks which significantly increase the interest and motivate students to learn. Based on this research, students give positive responses towards the application of formative assessment. It means feedback support students motivation to learn. Second, it has been done by Henderson et al. (2019). This research emphasized on students' comments. The feedback is used to direct students' interactive communication. The challenges are about the production of useful comments and perceived hurdles of both teacher and students' attitudes and capabilities. Third, it has done by Nassaji (2020). The conclusion of this research is one way to correct learners' errors is using feedback. The role of feedback has used in various measures to assess its usefulness. What we can adapt from these research papers is, using feedback is the way to give comment to the learners' achievement and progress, whether it is useful or not, it is the relation with students' condition and teachers' ability in delivering feedback.

Carrying out learning activities that begin with determining learning objectives and ending with assessment to get feedback seems very easy to accomplish when it is carried out in normal classes. But it will be different in its implementation if it is carried out in offline classes where the teacher's role is given virtually. Especially in the language learning that requires a lot of effort because learning a language is optimizing skills, namely speaking; writing; listening; and reading; which in a small part of learning a language is the ability of students to master vocabulary.

As we know that vocabulary is the essential thing in learning language. Especially in learning second language and foreign language. English is one of the subjects of Indonesian learners. Therefore learning vocabulary as the important starting point to learn English language. Teaching vocabulary is a priority in foreign language learning and it is the basic to be acquired by autodidact (Patahuddin et al., 2017). It is also stated that the vocabulary is believed that the students who more master vocabulary, they are easier to develop the four language skills, reading, listening, speaking, and writing (Patahuddin, et. al., 2017).

Since the pandemic of Covid-19, the students have to study at home through online learning. In addition, the relation of feedback and assessment is the essential part 
in education program. Especially in Language learning which needs interactive communication among students and teachers. Then feedback is the one of the strategies to communication. Based on the importance of learning vocabulary and the ways of students' learning namely learning from home, this paper aims to provide the result of observation and interview of Junior High School students, about how they learn English vocabulary at school and online learning by using semi-structured interview.

\section{METHOD}

\section{Research Design}

The researcher applied descriptive qualitative method for completing this research. In this research, the researcher essentially describes the situation in which how is the influence of feedback in different way of learning and the relationship with students' vocabulary acquisition. In order to answer the formulated research question the instrument used in this research was interview guideline.

\section{Procedures}

Some procedures in this research were; (a) select the subject, (b) observing the way of learning, (c) interviewing the subject about: 1) Which one is better online learning or study at school?, 2) What is the reason?, 3) How do you learn vocabulary?, (d) analyzing the result of the interview, (e) make the conclusion.

This research is focused on the vocabulary learning of Junior High School Students, the differences of study at school and study at home. The subjects are two Junior High School Students who study by using cellular phone to interact with teachers. They are seventh grade students who are studying at the same school but different classes and teachers.

\section{RESULTS AND DISCUSSION \\ Result of Interview on Students Student 1}

Related to the research, the interview has given to student 1 . The first question is about the choice whether she prefer the online or classroom in the process of learning. She answered that she prefers to study at classroom rather than online learning. The reason stated by Student 1 is she is able to ask question directly to the teacher when she doesn't understand about the material. When she learn English, she open the book, find 
the difficult words and ask to the teacher directly when she doesn't know the meaning of the difficult word. Because, sometime she opens the dictionary and finds the difficult explanation about the meaning of the words, so that she needs more explanation from the teacher. While she listened the explanation from the teacher, she can add her vocabulary directly. It is different when she does online learning. There are so many difficult words on the reading material when she studies at home. She confused about who can help her if she found difficulties, since people at home (parents, brother, and sister) could not help her like teachers do in classroom. She also stated that she makes note while the teacher is explaining. The notes are included the new vocabulary and each meaning in Bahasa Indonesia. The notes help her to add her vocabulary knowledge.

\section{Student 2}

The second subject is different class with the first subject. Questions that asked to the student 2 are the same. She stated that she preferred study at school than online learning at home. The reason why she prefers study at school is almost the same with Student 1. She often finds difficulties when learning English. But she has different way to solve the difficulties. She didn't ask directly to the teacher. She prefers to discuss with other friend about the difficult material. Then, if she and her friend cannot solve the problem she asks to the teacher. About how does she learn vocabulary, she cooperates with her friend to add minimally five words in a day. The words are used to the dialogue in a simple communication with friends. So, the vocabulary will develop gradually by practicing. The condition of online learning at home is different as she stated that she is often interrupted by her little daughter. It makes her difficult to be focused on learning. She cannot learn well and the duty from the teachers cannot submitted on time.

\section{Discussion}

Based on the both result of the interview student 1 and student 2, both of them prefer to study at classroom than online class. Because they are able to interact directly with the teacher who can help them to increase their vocabulary acquisition. As stated by Hanum, classroom needs interaction, the effective interaction in classroom will help students' language performance (Hanum, 2017). The language performance is included 
vocabulary learning and acquisition. The importance of classroom interaction also help teachers to improve their teaching.

Student 1 and student 2 have the similar opinion about the process of online learning which they did at home. Their vocabulary improves better when they study at school because they need teacher to help them in explain the difficult words and give the new words when the teacher explains the material. It is different when they study at home; they did online learning which cannot interact directly with the teacher. Unfortunately, the people at home cannot do the same as teachers do to explain what they do not understand. So, they have difficulties to understand the meaning of the difficult words which can influence in the process of vocabulary acquiring.

Then there is the relation among the three main components of this paper. In online class, students cannot get direct feedback which can help them achieve learning goals. Besides, the way in giving feedback of teachers is different. It has influence on students' vocabulary acquisition. Because when teachers give feedback at school, they use English in delivering the respond or feedback to the students. So, students are able to add their vocabulary by hearing teachers' explanation.

\section{CONCLUSION}

Language is important in human life, it can be explained that language as a meaningful function or whole (Munfaridah, 2017). Since English is considered as world language, the process of teaching and learning become the importance. It will influence language proficiency. As stated by Klein (1988), generally, language proficiency is defined as the ability to use language in effective and appropriate way. The four skills of language, listening, reading, writing, and speaking are the skills which have to be achieved by students. By improving their vocabulary, they will be easier to study the four skills. Because learning language is about learning the meaning. We will not be able to do the four skills without vocabulary.

Vocabulary acquisition is gained by communicative interaction. In language learning communicative interaction occurs in classroom activities. In this paper has been obtained that the subjects (Student 1 and Student 2) prefer to study at classroom than online class. Because they need teacher to explain the material. The interaction among teacher and students are important. It cannot be replaced by online classroom. Some condition, there are students who enjoy online class and interacting with the 
The Influence of Feedback in Different Way of Learning and the Relationship with Students' Vocabulary Acquisition: Issues in Assessment

teacher by texting. But other students may need their teacher to learn. In other mean, that the interaction (of course, including feedback) is better than online class.

In addition, vocabulary acquisition will be achieved better in classroom interaction than online learning. Because learning language need social interaction and classroom activity is one of social interaction among teacher and students. Then in doing alternative assessment teachers need to give feedback as the tool for communication with students. Based on the result of this research, students also needs feedback from teachers as their reflection and correction. So, they can improve their learning way.

Further research is necessary to reveal the vocabulary acquisition in the different kind of students' personality. Because their personality is different. There are students who extrovert, introvert, active, passive, and so on. The next research also can be conducted by considering the way of learning or learning style which there are students who have visual learning, auditory, kinesthetic, and other preferences in the way of learning.

\section{REFERENCES}

Admaja, R. K. (2020). Google Classroom as E-learning Mode at SMP YPM 7 Sidoarjo. JournEEL (Journal of English Education and Literature), 2(2), 34-44. https://doi.org/10.51836/journeel.v2i2.167

Douglas, D. (2014). Understanding language testing. Routledge.

Hanum, N. Susani. 2017. The Importance of Classroom Interaction in The Teaching of Reading in Junior High School. Seminar Nasional Mahasiswa Kerjasama Direktorat Jenderal Guru dan Tenaga Kependidikan Kemendikbud 2016.

Henderson, M., Ryan, T., \& Phillips, M. (2019). The challenges of feedback in higher education. Assessment \& Evaluation in Higher Education, 44(8), 1237-1252. https://doi.org/10.1080/02602938.2019.1599815

Jannah, S., Suryanto, \& Pratitis, N. T. (2021). Teacher's Strategy in Improving Slow Learners' Competence on Distance Learning at SMP Negeri 3 Krian Sidoarjo. JournEEL (Journal of English Education and Literature), 3(1), 45-54. https://doi.org/10.51836/journeel.v3i1.190

Khoiriyah, R., Latief, M. A., \& Astuti, U. P. (2018). Profile of English Successful 
The Influence of Feedback in Different Way of Learning and the Relationship with Students' Vocabulary Acquisition: Issues in Assessment

Students at Junior High School. Jurnal Pendidikan Humaniora, 6(1), 48-60.

Klein, W. (1988). Second Language Acquisition. International Encyclopedia of the Social \& Behavioral Sciences. https://doi.org/10.2307/414588

Munfaridah, N. (2017). ENGLISH TEACHING LEARNING PROCESS IN HOMESCHOOLING (A Descriptive Study to The Seventh Grade Students at Homeschooling Kak Seto Solo in Academic Year 2015/2016).

Nahadi, N., Firman, H., \& Farina, J. (2015). Effect of feedback in formative assessment in the student learning activities on chemical course to the formation of habits of mind. Jurnal Pendidikan IPA Indonesia, 4(1), 36-42.

Nassaji, H. (2020). Assessing the effectiveness of interactional feedback for L2 acquisition: Issues and challenges. Language Teaching, 53(1), 3-28. https://doi.org/DOI: 10.1017/S0261444819000375

Patahuddin, P., Syawal, S., \& Bin-Tahir, S. Z. (2017). Investigating Indonesian EFL Learners' Learning and Acquiring English Vocabulary. International Journal of English Linguistics, 7(4), 128. https://doi.org/10.5539/ijel.v7n4p128

Saeed, M., \& Moqbel, S. (2002). 5 . Alternative Assessment in EFL Classrooms : Why and How to Implement It! Journal of Language Teaching and Research, 4(2), 5679. http://www.academia.edu/download/51233614/Published

_Alternative_Assessment_in_EFLClassrooms_-

_Why_and_How_to_implement_it.pdf

Seli, S. (2015). Teaching English through Online Games for Junior High School Students. PREMISE JOURNAL:ISSN Online: 2442-482x, ISSN Printed: 20893345, 4(1), 1-10. https://doi.org/10.24127/pj.v4i1.281

Shohamy, E. (2017). ELF and critical language testing. In The Routledge handbook of English as a lingua franca (pp. 583-593). Routledge.

Yambi, A. C., \& Dictionary, W. (2012). Cases on Assessment and Evaluation in Education. Cases on Assessment and Evaluation in Education, 1-9. https://doi.org/10.4018/978-1-4666-2621-8 